\title{
Board games as tools for developing character independence in Malang Regency
}

\author{
C.U.C. Nursyifani, L.T. Atmaji \& G. Febriani \\ Bina Nusantara University, Malang, Indonesia
}

\begin{abstract}
Ages 0-5 are the ages during which a child's brain develops very rapidly. During this time, children learn by imitating so that the characters formed at the beginning of a child's development are similar to the characters of the people closest to them. At those ages, children learn to develop cognitive, psychomotor, discipline, independence, social, and emotional character through activities at home and at school (preschool). Children learn these things by using games and their daily habits. Currently, there are a lot of educational games, one of those being a board game. The research method used is qualitative with a child psychology approach (4-6 years), teacher opinion, and visual communication design theory. This psychological approach is used to determine a child's character so that it has an impact on the preparation of the concept of the game which includes the rules.
\end{abstract}

Keywords: board game, characters, preschool

\section{INTRODUCTION}

Children begin to learn things by imitating older people. According to Bandura, social learning theory can form an individual personality in response to social stimuli, which will have an impact on the good formation of character of a nation's generation. The process of observing and imitating the behavior and attitudes of others is an act of learning. The Bandura theory explains human behavior in the context of continuous reciprocal interaction between cognitive, behavioral, and environmental influences. Environmental conditions around children are also very influential in social learning patterns (Bandura 1974).

One characteristic of psychological development in kindergarten children aged 4-6 years is the emergence of children's desire to take care of themselves or be independent. Independence is a positive habit and this attitude of independence is also a component of the formation of social life skills, namely the ability of children to be able to adjust to their social environment (Sidharto \& Izzati 2007).

Therefore, alternative media is needed to help children develop character from an early age that is fun so that children of preschool age can socialize and act according to existing rules. Schools have a variety of instructional media for preschool children in terms of character development using a play approach method. There are so many types of learning media that can stimulate children's development through games.

Learning activities for preschoolers are dominated by doing daily activities and playing, therefore educational games are often found in school playgroups and kindergartens. Games provided by schools aim to help children grow and develop. Games that are suitable for the preschool-aged children include interactive books, block games, board games, etc.

In the current digital era, game-based teaching media easily can be found on practical digital/smartphone tools and certainly is very interesting for preschool-aged children. However, digital learning doesn't adequately stimulate a child's motor skill, so children become lazy to move their bodies because they are too focused on the smartphones. One tool that has the potential to stimulate 
Table 1. Development stages of children aged 48-72 months.

\begin{tabular}{ll}
\hline Stage Development* & Child Development \\
\hline 48-60 Months & $\begin{array}{l}\text { Stand on one foot } 6 \text { seconds, Looping } 1 \text { foot, Dance, Drawing (a cross, a circle), Draw- } \\
\text { ing people with } 3 \text { body parts, Buttoning up doll clothes or clothes, Call the full name } \\
\text { without assistance, Nice to mention new words, Nice to ask about anything, Answering } \\
\text { questions with correct words, The talk is easy to understand, Can compare/distinguish } \\
\text { something from its size and shape, Call the numbers, count fingers, Call the names } \\
\text { of the day, Self-dressing without help, Brushing teeth without assistance, React calm } \\
\text { and not fussy when left by the mother. } \\
\text { Walking straight, Stand with one foot for 11 seconds, Draw with 6 parts, draw complete } \\
\text { people, Catch a small ball with both hands, Draw a quadrilateral, Understand the } \\
\text { meaning of the opposite word, Understand conversations that use } 7 \text { or more words, } \\
\text { Answering questions about what objects are made of and their uses, Known numbers, } \\
\text { can count numbers 5-10, know colors, Expressing Sympathy, Follow the rules of the } \\
\text { game, self Dressing without help. }\end{array}$
\end{tabular}

* Pedoman Pelaksanaan: Stimulasi, deteksi dan intervensi dini tumbuh kembang anak ditingkat pelayanan kesehatan dasar. Kementrian Kesehatan Republik Indonesia 2013.

children is board games because this game can stimulate a child's thinking, language development, psychomotor abilities, and emotions.

According to the Pedoman Pelaksanaan: Stimulasi deteksi dan intervensi dini tumbuh kembang anak ditingkat pelayanan kesehatan dasar Kementrian Kesehatan Republik Indonesia 2013, children have characteristics that grow from the time of conception until the end of adolensnce. Development is the increase in the structure and function of the body which is more complex in the development of psychomotor, speech, and language abilitites, as well as socialization and independence. In terms of character development, preschoolers need to be given stimulation, especially related to the exercise of independence and socialization. Another stimulation that also needs to be grown are the cognitive and psychomotor abilities of children. Table 1 shows the stages of development of children aged 48-60 months and 60-72 months.

The definition of a tabletop game is a game that is played on the surface of a table. One type of tabletop game is a board game. The definition of a board game is a game in which there are rules on how to play which are equipped with several game components such as tokens, pawns, or pieces that can be moved on a special board. As time has evolved, the types of board games today are more varied (Tan et al. 2015):

1. Classic Board Games/Family Games. Players race around the board game or follow specific paths to reach goals. Sometimes a point collection system is also used. The essence of this game lies not in the game but from the experience of togetherness players. An example of this type of game is Snake and Ladder.

2. Euro-Style Games. This game requires players to collect points. The winner of this game is the player who collect the most points. Examples of this type of game are Catan, Power Grid, Carcassonne, and Lancaster.

3. Deck-Building Games. This game is similar to trading card games - each player has several sets of cards that will be used to play. Examples of this type of game are Dominoes and Thunderstorms.

4. Abstract Strategy Games. The essence of this game is the players collide strategy to defeat or trick each other. Examples of this type of game are Chess, Checkers, and Push Fight.

5. Strategy Games. This game has a story that is very important to direct the player. This game involves cooperation and competition and requires a high level of thinking. Examples of this type of game are Risk, Empire, Arkham Horror, and so forth.

6. Card-based Strategy Games. A strategy game where cards are a very important element. An example of this type of game is 7 Wonders. 
The variations of the games aim to make players more challenged with the flow of the game. Therefore, in making games, a game development process is needed which is divided into several stages. The game development process is broadly divided into the following stages (Nugroho 2013):

1. Research Phase and Concept Development. At this stage, basic ideas, objectives, themes, target audiences, technology, media (platforms), and various other limitations are formulated. This research stage becomes a crucial stage, various basic elements of a game are arranged here.

2. Formulation of Gameplay. At this stage, the game designers formulate gameplay/game mechanics that will be used in a game. This gameplay also regulates how a player can meet the objectives of the game and get a pleasant playing experience.

3. Arrangement of Asset and Level Design. This stage focuses on the conceptualization of all the characters and assets (including sound/music) needed. At the same time, the team also began to do the level design or grouping of levels of difficulty and various appropriate assets at each level (if there are more than one level) so that the game can present an optimal playing experience.

4. Test Play (Prototyping). At this stage, a prototype/dummy is presented to test the gameplay and various concepts that have been arranged, both at each level and as a whole, as well as making various improvements needed. This stage also serves to provide a complete picture for the whole team so that it can facilitate the process of further development.

5. Development. At this stage, all concepts (characters and assets) that had previously been arranged began to be fully developed. The game engine began to be developed, and all elements began to be integrated.

6. Alpha/Close Beta Test (UX-Initial Balancing). The main focus at this stage is to find out if all the main components of the game have been able to provide user experience as expected as well as to detect technical problems that have not been detected in the previous stages.

7. Release. At this stage, the game is ready to be released and introduced to the target players. When a game has been released to the public, it does not mean the development process is complete. Games in general continue to be optimized (updated). This is to ensure that the game that is presented is really able to provide the maximum playing experience.

The literature study above states that the development of children aged 4-6 years includes cognitive, motoric, and character development. At this age, the child begins to develop an independent character. Games that are suitable for the age of preschoolers include interactive books, block games, board games, etc. These games can stimulate a child's thinking, language development, psychomotor ability, and emotions.

The targeted findings in this study are able to compile content related to developing the character of independent preschool children (4-6 years) in Malang Regency. The purpose of this research is to help teachers and parents in adding variety to the game they play in terms of developing children's character through non-digital learning tools.

\section{METHOD}

The research method used is qualitative with a child psychology approach (4-6 years), teacher opinion, and visual communication design theory. The qualitative approach is a study aimed at describing and analyzing the phenomena, events, social activities, attitudes, beliefs, perceptions, and thoughts of people individually or in groups (Sukmadinata 2005), while the psychology approach is used to determine a child's character so that it has an impact on the preparation of the concept of the game which includes the rules of the game.

This research took place in two kindergarten locations in Malang. The primary research object is preschool children, both male and female, aged 4-6 years, as well as parents and teachers as secondary research objects. Data sources used in this study include written data in the form of field notes, research results, observations, scientific articles from previous research artists, and in-depth interviews. Data collection methods include the following. 

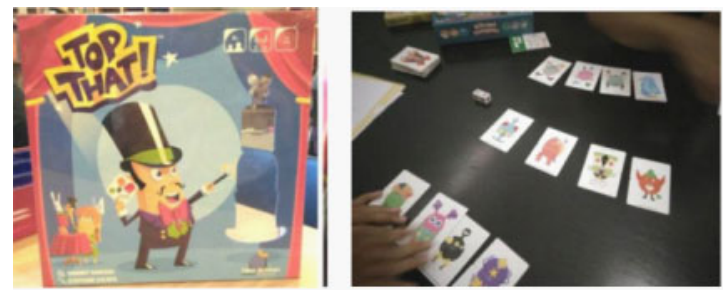

Figure 1. Top That! game, Fold It! game, and Mash Up Monsters game.
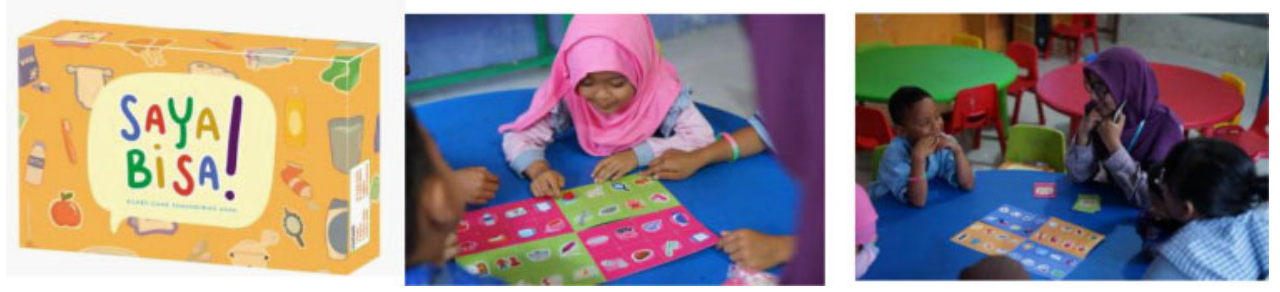

Figure 2. Saya Bisa! board game prototype test to preschool childrens.

1. Observation and identification are carried out to observe the condition of the object of research and to identify the problem under study. Observation locations were carried out in kindergartens, board game cafes, and board game developers.

2. Documentation and observation are carried out together before the interview process is carried out until the interview process takes place. On the next visit, the researcher began to compile an interview protocol that would be submitted to the principal, teachers (four people), board game developers (three people), board game café staff (two people), and pre-school children (five children aged 5 years).

3. Interview (in-depth interview) using semi-structured techniques with instruments in the form of interview guides. The selection of speakers is based on experts in their fields.

\section{RESULTS AND DISCUSSION}

Based on the results of interviews with psychologists, independence is the ability to solve problems on your own. The independence of pre-schoolers can be seen when they are able to complete tasks, tidy up things, and help others. Preschoolers are happy if they get a reward or praise for completing a given task.

The results of an interview with the principal stated that the media owned by the school in supporting the development of independence characters were in the form of picture books and daily habituation. Children aged 4-6 years tend to be curious and really like to be given a gift when they are able to complete the task. Gifts do not have to be expensive objects or items, but enough with the provision of star stickers or the words "smart kids".

The results of an interview with the board game designer found that children like playing games by playing mix and match. That is, children like games with the aim of matching the same picture. Based on previous literature studies, the game to be used is Euro-style games, where the player who collect the most points is the winner.

Examples of card games recommended by experts include "Top That!" and "Mash Up Monsters". These games use cards as clues to the mission to do. The rules of the game are almost the same, only different themes and materials. The flow of an easy game becomes important because children aged 4-6 years have limitations in reading and understanding instructions. 
The author created a prototype board game called Saya Bisa! Using previous games as a role models, the theme of this game is the daily activities in preschool children. Children are trained to be brave and actively answer or carry out a mission provided. The components contained in this game are image boards containing surrounding objects, meeple/pawns, question cards and mission cards, gold and silver coins, and medals.

\section{CONCLUSIONS}

The board game prototype Saya Bisa! made based on the results of observations and interviews that have been conducted. Board game prototype Saya Bisa! is the theme of daily activities using the help of illustrations of surrounding objects. The use of illustrations is because preschool children are not fluent in reading. This game teaches children with a happy atmosphere. Children easily absorb new things with the method of play.

The advantage of the concept given is that this game can develop a character of independence with several kinds of challenge. Children dare to answer, dare to tell stories, and can complete a challenge. The disadvantage of this game is that if there is no adult assistance, so children will have difficulty in running the game. The next research recommendation is to simplify the flow of the game so that children can play without too much assistance from adults.

\section{ACKNOWLEDGMENTS}

The authors want to thank Wikan Prabowo, Kummara/Manikmaya game designer, the H'Dr Comic Café staff, and Tabletops Boardgames Library staff, who participated as experts for the interviewing this research. The authors also want to thank to PAUD Al-Furqan Malang and RA Miftahul Jannah-DAU for contributing as an object of research.

\section{REFERENCES}

Bandura, A. 1974. Behavior theory and the models of man. American Psychologist 29(12):859- 869.

Kementrian Kesehatan Republik Indonesia. 2013. Pedoman Pelaksanaan: Stimulasi,deteksi dan intervensi dini tumbuh kembang anak ditingkat pelayanan kesehatan dasar, Jakarta 13-14.

Nugroho, Eko. 2018. Soal game, jangan sampai kita blunder. Retrieved from https://kumparan.com/ eko-nugroho/soal-game-jangan-sampai-kita-blunder-ngobrolgame/full.

Nugroho, Eko. 2013). 7 tahap pengembangan game. Retrieved from https://tekno.kompas.com/read/2013/ 08/21/1226508/7.Tahap.Pengembangan. Game?page=all.

Sidharto, S. and Izzaty, R. E. 2007. Pengembangan kebiasaan positif: 16-19. Yogyakarta: Tiara Wacana.

Sukmadinata, N.S. 2005. Metode penelitian pendidikan:60 Bandung:Remaja Rosdakarya.

Sukmasari, R.N. 2016. Manfaat main board game bagi anak: latih strategi hingga kontrol energi. Retrieved from http://m.detik.com/health/read/2016/03/16/143225/316 6187/ 1301/manfaat-main-board-game-bagianak-latih-strategi-hingga-kontrol-emosi?1992203755.

Tan, S., Suwasono, A.A., and Yuwono, A. 2015. Perancangan Board Game Pengenalan Dinosaurus Untuk Anak Usia 8-12 Tahun. Jurnal DKV Adiwarna, 1(6):10. 